\title{
Possible NP-positions in constructions with directional adverbs and prepositions
}

\section{MICHAEL NGUYEN}

In this paper, two types of constructions are analyzed: (i) Constructions where an NP (noun phrase) precedes a directional adverb, e.g. Australien rundt 'Australia around', liv-et ud 'life-the out' and et andet sted hen 'another place to', and (ii) constructions where the NP follows the directional adverb (and a preposition), e.g. rundt om Australien 'round about Australia', ud i liv-et 'out in life-the' and hen til et andet sted 'to to another place'. The analysis is based on generative standard assumptions about the structure of phrases and about case assignment of NPs, one of which is that an NP must be assigned one and only one case. The analysis is also based on the existence of the so-called $p$ P-constituent, i.e. a constituent of which the directional adverb $p$ is the head selecting a PP as its complement, e.g. $\left[_{p \mathrm{P}}\right.$ rundt $\left[_{\mathrm{PP}}\right.$ om Australien], lit. 'around about Australia'. It is furthermore an important assumption that the $p$-element can select a PP with an implicit or covert preposition $\mathrm{P}$ (i.e. some kind of null morpheme). On the basis of the $p \mathrm{P}$-structure and all the above-mentioned assumptions, the analysis accounts for why constructions such as rundt om Australien and Australien rundt (both meaning 'around Australia') are grammatical, whereas constructions such as *rundt Australien or *Australien rundt om are ungrammatical. In the grammatical constructions, the NP is assigned one and only one case (either by a $p$-element or by $\mathrm{P}$ ). In the ungrammatical constructions, the NP is either not assigned any case, or it is assigned two cases.

KEYWORDS: case; directional adverbs; prepositions and postpositions; $p \mathrm{P}$; generative linguistics 